Article

\title{
Using Food Flow Data to Assess Sustainability: Land Use Displacement and Regional Decoupling in Quintana Roo, Mexico
}

\author{
Marco Millones ${ }^{1, *}$, Benoit Parmentier ${ }^{2}$, John Rogan ${ }^{3}$ and Birgit Schmook 4 \\ 1 Department of Geography, University of Mary Washington, 1301 College Ave, Fredericksburg, \\ VA 23219, USA \\ 2 Sustainability Solutions Initiative, Mitchell Center, 5710 Norman Smith Hall, University of Maine, Orono, \\ ME 04469, USA; benoit.parmentier@maine.edu \\ 3 Graduate School of Geography, Clark University, 950 Main St. Worcester, MA 01610, USA; \\ jrogan@clarku.edu \\ 4 Colegio de la Frontera Sur, Chetumal, Av. Centenario km 5.5, Sin Número Exterior, \\ Colonia Pacto Obrero Campesino, CP 77014, Quintana Roo, Mexico; bschmook@ecosur.mx \\ * Correspondence: mmillone@umw.edu; Tel.: +1-305-298-8542
}

Academic Editor: Hossein Azadi

Received: 17 September 2016; Accepted: 2 November 2016; Published: 8 November 2016

\begin{abstract}
Food flow data provide unique insights into the debates surrounding the sustainability of land based production and consumption at multiple scales. Trade flows disguise the spatial correspondence of production and consumption and make their connection to land difficult. Two key components of this spatial disjuncture are land use displacement and economic regional decoupling. By displacing the environmental impact associated with food production from one region to another, environmental trajectories can falsely appear to be sustainable at a particular site or scale. When regional coupling is strong, peripheral areas where land based production occurs are strongly linked and proximate to consumption centers, and the environmental impact of production activities is visible. When food flows occur over longer distances, regional coupling weakens, and environmental impact is frequently overlooked. In this study, we present an analysis of a locally collected food flow dataset containing agricultural and livestock products transported to and from counties in Quintana Roo (QRoo). QRoo is an extensively forested border state in southeast Mexico, which was fully colonized by the state and non-native settlers only in the last century and now is home to some of the major tourist destinations. To approximate land displacement and regional decoupling, we decompose flows to and from QRoo by (1) direction; (2) product types and; (3) scale. Results indicate that $Q R o o$ is predominantly a consumer state: incoming flows outnumber outgoing flows by a factor of six, while exports are few, specialized, and with varied geographic reach (Yucatan, south and central Mexico, USA). Imports come predominantly from central Mexico. Local production in QRoo accounts for a small portion of its total consumption. In combining both subsets of agricultural and livestock products, we found that in most years, land consumption requirements were above $100 \%$ of the available land not under conservation in QRoo, suggesting unsustainable rates of land consumption in a 'business as usual' scenario. We found evidence of economic regional decoupling at the state level.
\end{abstract}

Keywords: food flows; land use displacement; environmental impact; consumption; agriculture; livestock; Yucatán 


\section{Introduction}

An important goal in the search for sustainability is the generation of food systems that balance the trade-offs between human activities and environmental conservation, so that in the long run, levels of production meet present and future human demand, without threatening the structure and functioning of the biophysical system of the planet [1,2]. The impact of human food production systems has been largely documented (e.g., natural land cover loss, soil exhaustion, climate change, water pollution, gas emissions, etc.) [3-5]. However, with increased affluence in some regions and a rapidly globalized and interconnected world, the impact of food consumption in one locality often appears to be disconnected from the food production sites that support it $(2015[6,7]$. This spatial disjuncture makes the impacts of food production and consumption less visible, harder to quantify, and more difficult to govern [8-10]. In this context, scholars, policymakers and local actors are increasingly interested in strategies to account for the stresses on the environment associated with the production of food at different scales, and to couple these strategies with efforts to make environmental impacts more visible or costly to the final consumer $[9,11]$.

Historically, efforts to control environmental degradation have focused on managing demand size (population control), consumption type (product bans), technological changes (intensification, green revolution), and institutional arrangements (power/resource/land redistribution, land sharing vs. land sparing) $[4,12]$. While these strategies would arguably result in desirable sustainable outcomes at a planetary system scale, their implementation, which typically has occurred at the nation-state scale, has had mixed results. Global food systems operate through the juxtaposition of transnational profit-driven production networks and local production systems. Regional food systems, in turn, are mediated and fragmented by politically and culturally based governance structures at the nation-state scale, or by ad hoc strategic regional coalitions motivated by trade or geopolitics (e.g., European Union, EU, North American Free Trade Agreement-NAFTA). This mismatch of operational scales complicates the applicability of the planetary scale based sustainable "solutions", especially given that global environmental governance is weak and subordinated to nation-state priorities. Given the global nature of the problem, national, regional, or local initiatives are likely to provide partial, or suboptimal outcomes-i.e., an arrangement that is optimal for one region might be unsustainable for another $[6-8,13]$.

The problem of accounting for the sustainability of food production and consumption in a multi-scale, interconnected context is particularly evident for land-based measures of sustainability related to the impact of food production on the environment (e.g., percentage of area under forest cover, forest recovery, soil loss, erosion) [8,9]. Scholars in disciplines focused on land system science $[14,15]$ are aware that local impacts on land are rarely circumscribed to local drivers alone, and that there is an increased need for multi-scale indicators of sustainability that take trade and flows into account $[10,16-22]$. However, many national and sub-national governments continue to rely on in-situ local indicators to measure environmental impact outcomes of production activities. These measures, typically circumscribed to a political administrative region, tend to be reported as summaries over space and time (e.g., deforestation rate), or as measures of the spatial pattern and/or temporal trajectory of a specific metric (e.g., landscape ecology fragmentation measures) [23]. A common benchmark of sustainable outcomes in these contexts is an idealized return to a natural state (e.g., $100 \%$ forest recovery), or alternatively a transition toward an "efficient" zoning scheme within a region that intensifies productive areas while sparing areas for conservation [4,24-26].

A good illustration of how local or national scale indicators, that neglect flows and non-local drivers, are problematic for measuring sustainable outcomes through spatio-temporal trajectories, are early applications of the forest transition framework $[27,28]$.The forest transition framework proposes that in the process of modernization, economies transition from mostly rural, extractive activities to principally urban (secondary and tertiary) activities [25,29]. "Modernized" rural areas become specialized in terms of production and in space (i.e., concentrated in highly productive lands), which allows for increased outputs and increased yields [30]. As a consequence of this modernizing process, 
large parts of rural areas "recover" from extractive uses and "revert" back to extensive land uses and land covers (e.g., forest, recreation) [30,31]. However, cases of forest transition can also be caused by processes that are very different from modernization and endogenous development, such as massive land abandonment due to political violence, as in El Salvador [32] or the effect of male outmigration and remittance economies in Mexico [33]. More importantly, there is now awareness that focusing only on the temporal trajectory of land change and neglecting its spatial dimension can cause an overstatement of claims about the relationship between forest transition trajectories and sustainability. On the one hand, a forest transition can produce sustainable (optimal) landscapes at a national level that are sub-optimal or even unsustainable at local or coarser global scales [34]. On the other hand, neglecting spatial relationships such as trade or conflict among countries might over- or under-estimate the (un)sustainability of a country's land use patterns, and the economic activities and policies that produce them. As detailed above, some of the environmental impacts may be exported to external distant regions so that the forest transition observed in a location may reflect a shift in trade flow and decoupling rather than a true intensification or decrease in local environmental impact.

More recent conceptualizations have combined temporal and spatial dimensions in the study of land use (dis)intensification processes and patterns by incorporating trade and land-based commodity flows $[8,9]$. These frameworks link demand for land in one location to supply of land in non-local, non-adjacent rural landscapes (at regional, national, global scales). In this study, we focus on two frameworks. First, we examine regional economic decoupling processes $[17,35]$ where, over time, a traditional, adjacent rural hinterland becomes decoupled from its urban counterpart and, increasingly, becomes a product of consumption and demand from places outside of its region and country. Second, we consider displacement of land use $[20,21]$ where national scale forest transition trajectories are linked with an increase in trade of land-based commodities (e.g., timber, food) associated with land change (e.g., deforestation) in other countries. In general, decoupling and displacement can be understood as the same processes operating at different scales (urban-rural within a region in the former, and national-global, in the latter). The two match the strengths, scales of application and initial formulations of the Von Thünen model and forest transition framework, respectively. Decoupling and displacement of the production process, with increases in trade production and consumption flows, can also result in a redistribution of environmental impacts which can make it difficult for local or regional entities to control these impacts. Understanding such flows is therefore important to land change and sustainability sciences.

A related, implied idea in regional decoupling and land used displacement is linked to the ecological footprint concept $[8,16,36,37]$. A key implication of "footprint" analyses is that in the presence of trade, sustainable outcome measures should include explicit statements about the levels of consumption vis à vis production of environmental goods and services, including those that happen outside of the region's boundary. One way to operationalize this implication is to define sustainable outcome measures with respect to self-sufficiency as a benchmark. In this way, if consumption of a food product in a region matches the production levels of that product in that same region, then we can claim that that region meets a strict definition of sustainability. In addition, if measured over time, we can see whether the trend is increasing or decreasing, signaling a trajectory towards or away from sustainability. In terms of regional coupling, a region with a balanced production-consumption "book" implies a largely self-sufficient (and food secure), coupled region. In land use displacement terms, a "balanced book" implies fewer environmental impacts linked to food production that are "exported" to other regions, and fewer environmental impacts "imported" from other regions.

In addition to allowing a more complete estimation of land degradation, the measurement of environmental impacts and degradation of food systems at multiple scales is important because of the following points:

(1) Visibility: Ex situ environmental degradation associated with the production of food for a particular region becomes less visible as production takes place further away from the consumption region. Consumers are less likely to be aware of the potential environmental 
impact of their consumption when products originate from distant areas. Consumers also may have less attachment to the landscapes of production and less connection to the population impacted by consumption. This is particularly true when there is a weakening of proximate urban-rural relationships (e.g., hinterlands).

(2) Governance: In situ environmental degradation associated with the production of food for other areas is less governable by local and regional institutions. When outside actors such as governments or corporations are more powerful than the local ones, local government and other actors cannot fully control flows and environmental impacts [13].

(3) Food security: Estimating food security defined as the capacity of a region to feed itself, especially under situations of environmental or political-economic stress-becomes more problematic. Regions can become increasingly or fully dependent on outside trade flows (imported products). In addition, if there is a large component of the flows aimed at export, regional land use may or may not reflect that external dependency. Much of its productive land, even if used for food production, might not be destined to feed that region, but to feed other regions [9].

The present study focuses mostly on the first point described above, although it also touches upon some topics relevant to all three points. In contrast to previous studies of land use displacement, our research focuses on a national and sub-national scale. Attention to local and global causes and mechanisms may overlook the many meso-scale or regional relationships that transform landscapes. Key among those are the prevailing role of cities and regional settlement systems (i.e., traditional rural-urban hinterlands), and the increasing demand for productive local land by populations from very distant locations within and outside a country's borders.

We analyze flow data about food production and consumption from and to the state of Quintana Roo (QRoo), Mexico, across three spatial scales and over nine years (2001-2009). More specifically, we will first use the concepts of land use displacement [7,21] and regional decoupling [38] to link land systems science studies with food flows and sustainability measures. Second, we quantify, illustrate and describe types of intra- and extra-regional flows of livestock and unprocessed agricultural, and processed animal products from 2001 to 2009. Next, we approximate the potential land equivalencies contributed by each type of flow and destination (scale). Finally, we evaluate the evidence of land-use displacement to and from QRoo, and economic decoupling in the region. By doing so, we provide insights regarding the applicability of flow data and land change concepts to the measurement of land based sustainability measures and for understanding the changes underway in this part of southeastern Mexico.

\section{Study Area}

The state of QRoo resides on the flat, karstic, Caribbean coastline of the eastern Mexican Yucatán Peninsula [39,40] (Figure 1). During Spanish and early Mexican colonization, the Caribbean coast and interior lands remained relatively unoccupied, and provided a refuge for those Mayans seeking to escape state domination [41-43]. QRoo gained territorial status in 1898, marking a period of extractive forest activities for national and international markets [44]. Statehood was achieved in 1974 [45] as Mexico increasingly opened communal lands to smallholder farmers [46,47], and began to develop tourism along its northeastern coastline. Availability of land with formal tenure also triggered the arrival of migrant communities from other parts of Mexico, along with large-scale agricultural projects.

The North American Free Trade Agreement (NAFTA) accelerated the opening of the Mexican economy in the 1990s, triggering key transformations in domestic production of agricultural and livestock goods [48]. Aside from an increase in cheap imports from the USA and Canada, the thrust in competitive regional specialization and production efficiency altered the production base, rearranged regional commercial linkages, and modified the landscapes of many Mexican states, including QRoo in the Yucatán Peninsula [49].

In parallel, at present, large parts of QRoo have been redefined by the government as archaeo-eco-tourism zones, with large ecological and forest reserves that service as a centerpiece of 
the United Nations Mesoamerican Biological Corridor [46,50]. This, in addition to large conventional beach tourism developments in the northeast (e.g., Cancun, Playa del Carmen), define much of QRoo's present economic landscape. These developments have been aided by the consolidation of a road network across the peninsula, rendering QRoo much more accessible [51].

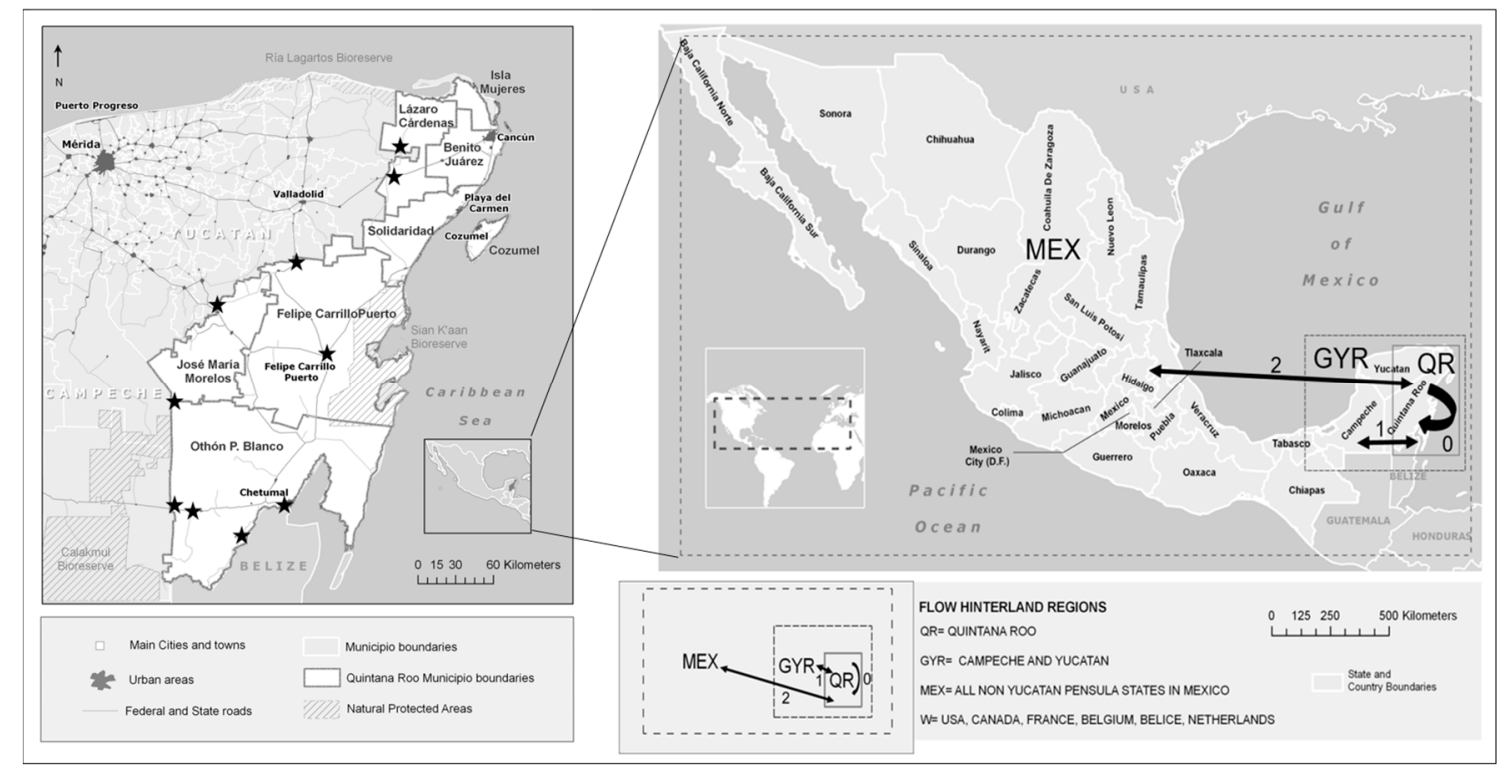

Figure 1. State of Quintana Roo showing data collection locations (black stars) (left panel). Hinterland region categories used in this study (right panel): (1) QRoo, corresponding to flows internal to QRoo; (2) GYR, indicating flows from or to QRoo's neighboring states of Yucatan and Campeche in the peninsula; (3) MEX, designating flows from or to the rest of Mexico (excluding GYR and QRoo).

Changes in the last three decades have accelerated the redefinition of QRoo's economic role in the national and international arena as a beach and archaeo-eco-tourist destination, with a few enclaves of highly efficient commercially oriented agriculture such as greenhouse production in Felipe Carrillo Puerto, or sugar cane fields in southern Othón P. Blanco [48,52]. While still important, forest production is not as significant as it was a century ago, and its current share of the timber market in the world is quite small and specialized [53-55].

In terms of land, landscapes in QRoo reflect only partially the economic structure and macro-economic narrative described above. While urban centers have increased in number and significantly encroached into former rural areas, a portion of the state is still being used for agricultural and livestock production activities, or covered by forests in different stages of ecological succession [56-58].

While QRoo has never been an isolated region [44,45], the effects of NAFTA, accelerated opening to global markets, and the parallel processes previously described have masked the spatial correspondence between land use and QRoo's regional economy. This has important implications for the prospect of balancing economic development and environmental sustainability in the long run, as set out in federal and state plans $[49,59]$. The first step toward achieving this balance is gaining clarity about the status quo in the relationship between trade and land use. Furthermore, QRoo is considered within the Mexican context, as a rich, and mostly consumer state, with little local production. As such, it is a good example of a region that displaces most of the land used to produce the food it consumes. Elements of forest recovery might hint at a sustainable trajectory, but as further analyzed in our research, the increasing levels of consumption tell a different story. 


\section{Methodological Approach}

Following the conceptualization of sustainability presented earlier, we present the instrumental framework used for this analysis, as it relates to the concepts of land use displacement $[20,21]$ and land use regional decoupling [17]. We apply this instrumental framework to the regional food system flow dataset from the State of Quintana Roo (QRoo), Mexico.

\subsection{Data Sources and Processing}

An alphanumeric database of agricultural, livestock, poultry, and meat product flows at the municipal level for 2001-2009 was obtained in 2010. The flow data of the different products mentioned are recorded daily at inter- and intra-state collection locations, known as casetas, from all vehicles transporting livestock, meat, and fresh agricultural products (Figure 1, Table 1). Casetas are data collection and control checkpoints managed by the Comité Estatal para el Fomento y Protección Pecuaria del Estado de Quintana Roo (State Committee for Livestock Promotion and Protection of the State of Quintana Roo) (CEFPPQR), a QRoo-based organization in charge of controlling the spread of animal and plant diseases and pests across states. CEFPPQR records daily flow data at the municipal level, including origin and destination, which ultimately gets reported in annual state aggregates to the Food and Agriculture Secretariat (SAGARPA).

Table 1. Datasets and sources.

\begin{tabular}{|c|c|c|c|c|c|}
\hline Data Item/Product & Source/Provider & $\begin{array}{l}\text { Spatial } \\
\text { Scale: }\end{array}$ & $\begin{array}{l}\text { Temporal } \\
\text { Scale: }\end{array}$ & Variables Derived & Type of Data \\
\hline $\begin{array}{l}\text { Flow of forest, } \\
\text { agricultural and } \\
\text { livestock products }\end{array}$ & $\begin{array}{l}\text { Comité Estatal para } \\
\text { el fomento y } \\
\text { protección pecuaria } \\
\text { del estado de } \\
\text { Quintana Roo S.C. } \\
\text { (CEFPPQR) }\end{array}$ & $\begin{array}{l}\text { State and } \\
\text { Municipal }\end{array}$ & $\begin{array}{l}\text { 2001-2009 } \\
\text { - daily }\end{array}$ & $\begin{array}{l}\text { hinterland indicator } \\
\text { transactions/shipment frequency } \\
\text { AGRI = agricultural production } \\
\text { LIVESTOCK = animal production } \\
\text { MEAT = meat and other animal } \\
\text { processed product including honey }\end{array}$ & $\begin{array}{l}\text { Counts } \\
\text { Metric Tons } \\
\text { Head count }\end{array}$ \\
\hline $\begin{array}{l}\text { Southern Mexico } \\
\text { Forest Cover and } \\
\text { Clearance for c. } \\
1990 \text { to c. } 2007 \\
\text { digital map }\end{array}$ & $\begin{array}{l}\text { Center for Applied } \\
\text { Biodiveristy-CABS } \\
\text { 2009. Derived from } \\
\text { Landsat TM and } \\
\text { Enhanced Thematic } \\
\text { Mapping Landsat } \\
\text { (ETM+) imagery }\end{array}$ & $\begin{array}{l}\text { - Southern } \\
\text { México } \\
\text { states } \\
-\sim 30 \mathrm{~m}\end{array}$ & $\begin{array}{l}\text { Compilations } \\
\text { for } 1990,2000 \\
\text { and } 2007\end{array}$ & $\begin{array}{l}\text { Land change/persistence classes: } \\
\text { Forest persistence (FP) } \\
\text { Non-forest persistence (NFP) } \\
\text { Forest-to-non-forest-change (CH) }\end{array}$ & Categorical \\
\hline
\end{tabular}

The CEFPPQR database was reclassified to identify three types of flows with respect to the anchor region (QRoo): Type A, (inflows), for products coming from outside of QRoo from any part of Mexico, including the Yucatan Peninsula; Type B (outflows), for products leaving QRoo to anywhere in Mexico; and, Type C (internal circulation) from any municipality in QRoo to any other municipality in the state (Figure 2, Table 2). An indicator of a region of influence, at different scales or categorical distance, called hinterland, was created for each record to summarize both origin and destination regions into fewer and more manageable groups and to facilitate decoupling analysis. Hinterland categories represent three aggregated scales of interaction between QRoo and other locations: Mexico (MEX), GYR (Yucatan Peninsula, including the states of Campeche and Yucatan), and QR for the state of Qroo itself (Figures 1 and 2). Land cover estimates were performed using CABS forest loss maps [60], which are based on Landsat 7 ETM+ imagery (Table 1).

In this research, flows are measured by counting transaction, shipment or movement events, as well as by product quantity or volume. Movement event counts correspond to the number of times a product was moved from origin locations to destination locations and vice versa. Product quantity or volume corresponds to the amount of product measured in an appropriate unit for a given product, i.e., in metric tons for agricultural (e.g., fruits and vegetables) and animal products (e.g., eggs, dairy and meat), but by a head count for livestock (e.g., bovine, swine). Table 1 provides a summary of the data and derived variables and indicators. 


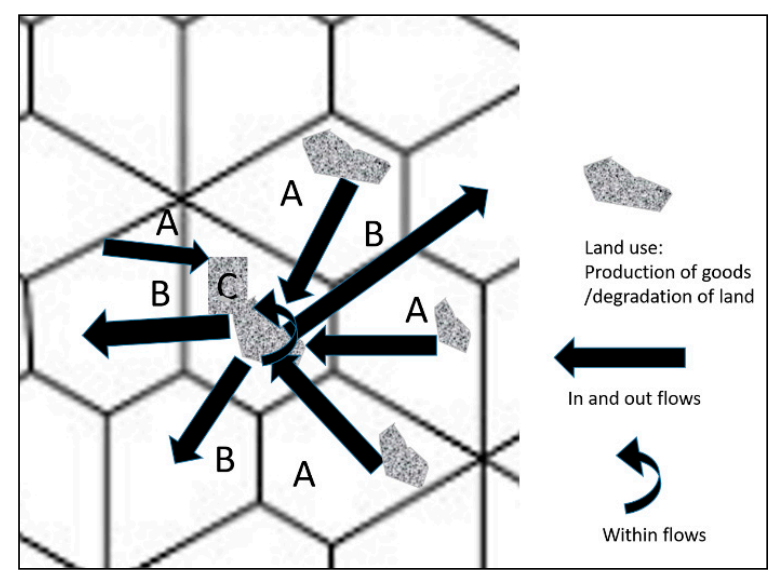

Figure 2. Type of flows generated from the dataset for an anchor unit (QRoo): Type A (inflows) from either the Greater Yucatan region GYR or Mexico (MEX) to QRoo; Type B (outflows from QRoo to either GYR or MEX); Type C (internal circulation) from any municipality in QRoo to any other municipality in the state.

\subsection{Land Displacement}

When flows are measured in quantity of products, they can be converted to land area units using conversion factors that correspond to the area of land used to produce a given quantity (e.g., crop yields per hectare, stocking per hectare for livestock, or feed area; see Appendix A). Using this method, we can estimate the portion of land used for food production in GYR and MEX to be consumed in QRoo (flows of type A $\times$ area conversion factor). This corresponds to the displacement of land use to GYR and MEX combined, contributed by QRoo, or the external land use, environmental 'land footprint', or environmental impact attributable to QRoo food consumption. Conversely, the amount of land within QRoo used to meet outside food demands from GYR and MEX (flows of type $B \times$ area conversion) estimate the displacement of land use to QRoo from MEX and GYR combined (see Figure 2). Table 2 summarizes and describes the types of flows and their combinations as they relate to land use displacement, and regional decoupling, and the analyses performed in this research.

Table 2. Types of flows (from Figure 2) and what they measure in terms of land displacement.

\begin{tabular}{ll}
\hline TYPE & Description \\
\hline A (inflows) & Land displaced from QRoo to GYR and MEX \\
\hline B (outflows) & Land displaced from GYR and MEX to QRoo \\
\hline C (wthinin flows) & Local internal land consumption/demand \\
\hline B + C & $\begin{array}{l}\text { Total potential land used for food production in QRoo linked to either internal } \\
\text { or external consumption/demand }\end{array}$ \\
\hline A + C & $\begin{array}{l}\text { Total land demand/consumption to meet consumption levels in QRoo Land } \\
\text { used in GYR and MEX and QRoo to be consumed/demanded by QRoo }\end{array}$ \\
\hline A + B + C & $\begin{array}{l}\text { Total impact of food production and consumption on land in anchor region in a } \\
\text { "business as usual” scenario }\end{array}$ \\
\hline
\end{tabular}

\subsection{Regional Decoupling}

The second component of sustainability clarified by flow data is the regional decoupling of an economy. To define and measure decoupling, we examined the intensity of flows between regions and within the region, with the expectation that a region that is fully coupled would interact most intensively with itself (it will display more internal flows). A decoupled region in contrast, would display more external flows, displaying a stronger interaction with other regions. 
To investigate decoupling, we use the hinterland indicator described above as a proxy to measure hinterland effects, linked to the classic Von Thünen formulation, and gravity models of spatial interaction. The hinterland indicator represents the expectation that the intensity of flows vary by distance, and that rural areas are expected to be the main providers of food commodities to urban centers. The hinterland effect can be measured at the scales of the geographic units shown in Figure 1, (MEX, GYR, QRoo), but also at a finer municipal scale to account for urban-rural decoupling.

Both land use displacement and decoupling are better interpreted when analyzed over time. As QRoo's regional economy transitions to a more globalized and teleconnected economy, we can expect more land use displacement and decoupling, which may mask environmental impacts either in the anchor region analyzed or regions outside.

\subsection{Consumption vs. Production}

To measure the degree of sustainability of QRoo's consumption vs. production levels, we compared both land and non-land flow components over time in our analysis. To do so, we plotted the quantity of flows and the estimated areas used to generate them in terms of consumption and production for each product type over time. Potential area estimates were obtained from converting quantities (in metric tons and a head count of cattle from the flow database) into area units (hectares) using yields for crops and stocking rates for livestock. Details on the products and conversion method and sources used to arrive at these estimates can be seen in Appendix A. Available land for QRoo was estimated based on the CABS land cover map categories NFP and CH combined (Table 1). Overall, our goal in our selection of conversion methods was to be as conservative as possible in order to not over-estimate consumption of products and land, and the level of dependency of QRoo with respect to other regions for food provision.

\section{Results}

4.1. Main Trends: Inflows, Outflows and Internal Circulation Measured in Number of Shipments and Volumes by Type of Product

Results confirm that, overall, QRoo is a predominantly consumer state in terms of agricultural, livestock and animal products, as shown by its persistent negative trade balance and the asymmetry between ingoing and outgoing flows (Table 3). In the last decade, incoming flows (i.e., shipments for all types of products) outnumber outgoing flows by a factor of six. Eighty percent of inflows originated in GYR or MEX, while only $13 \%$ of all flows documented left the state for outside locations (type B, outflows). Even combining transactions within QRoo (type C) (6.43\% of all flows) with outflows, these still total four times less than inflows. When inflows are broken down by region of origin (MEX, GYR, QRoo), we see that in terms of total transactions/shipments, inflows to QRoo are nearly evenly split between GYR (37\%) and MEX (42\%). In contrast, outflows favor the closer destination region of GYR $(9 \%)$ over MEX (3\%) by a factor of 3 (Table 3$)$. When analyzed by type of product, we find that, irrespective of flow direction, out of all flow transactions $(400,310)$, roughly $82 \%$ $(160,354+168,575=328,929)$ of shipments correspond to agricultural and processed animal products combined (e.g., bovine, pork and poultry meat, eggs and daily). The remaining 71,381 transactions $(17.8 \%)$ correspond to livestock flows.

Measured by weight (metric tons), incoming agricultural products to QRoo outweigh the volume of outgoing products by a factor of 3 (flows type A and B, Table 4). In the case of livestock head, this ratio is at least $4: 1$. For animal products, inflows $(96.35 \%)$ exceed outflows $(3.39 \%)$ by a factor close to 30 . The majority of agricultural products $(63 \%)$ and half of animal product $(50 \%)$ volumes arriving in QRoo come from MEX. GYR provides most livestock heads (77\%), as well as $40 \%$ of animal products (especially poultry). 
Table 3. Total count or number of flow transactions/shipments by type for all years aggregated. Flows included by type: agriculture (AGRI), livestock (LIVESTOCK), and processed animal products (MEAT), and by $\%$ total of each type of product.

\begin{tabular}{cccccc}
\hline Flow & Direction & AGRI (\%) & LIVESTOCK (\%) & MEAT (\%) & Total (\%) \\
\hline \multirow{2}{*}{ Inflow (A) } & \multirow{2}{*}{ GYR-QR } & 62,409 & 44,719 & 44,317 & 151,445 \\
& & $(38.92)$ & $(61.65)$ & $(26.29)$ & $(37.83)$ \\
\hline \multirow{2}{*}{ Inflow (A) } & \multirow{2}{*}{ MEX-QR } & 71,428 & 2361 & 97,170 & 170,959 \\
& & $(44.54)$ & $(3.31)$ & $(57.64)$ & $(42.71)$ \\
\hline \multirow{2}{*}{ Subtotal (A) } & & 133,837 & 47,080 & 141,487 & 322,404 \\
& & $(83.46)$ & $(65.96)$ & $(83.93)$ & $(80.54)$ \\
\hline \multirow{2}{*}{ Outflow (B) } & \multirow{2}{*}{ QR-GYR } & 11,645 & 6388 & 20,459 & 38,492 \\
& & $(7.26)$ & $(8.95)$ & $(12.14)$ & $(9.62)$ \\
\hline \multirow{2}{*}{ Outflow (B) } & \multirow{2}{*}{ QR-MEX } & 7517 & 1426 & 4740 & 13,683 \\
& & $(4.69)$ & $(2)$ & $(2.81)$ & $(3.42)$ \\
\hline \multirow{2}{*}{ Subtotal (B) } & & 19,162 & 7814 & 25,199 & 52,175 \\
& & $(11.95)$ & $(10.95)$ & $(14.95)$ & $(13.03)$ \\
\hline \multirow{2}{*}{ Within (C) } & \multirow{2}{*}{ QR-QR } & 7355 & 16,487 & 1889 & 25,731 \\
& & $(4.59)$ & $(23.10)$ & $(1.12)$ & $(6.43)$ \\
\hline \multirow{2}{*}{ Total \% } & & 160,354 & 71,381 & 168,575 & 400,310 \\
& & $(100)$ & $(100)$ & $(100)$ & $(100)$ \\
\hline
\end{tabular}

Table 4. Flow quantities/volumes by type for all years aggregated. Flows included by type AGRI in metric tons, LIVESTOCK in head, and MEAT in metric tons, by \% total of each type.

\begin{tabular}{|c|c|c|c|c|c|}
\hline Flow & Direction & $\begin{array}{c}\text { AGRI } \\
(\%)\end{array}$ & $\begin{array}{c}\text { LIVESTOCK } \\
(\%)\end{array}$ & $\begin{array}{l}\text { MEAT } \\
(\%)\end{array}$ & $\begin{array}{l}\text { Total } \\
(\%)\end{array}$ \\
\hline Inflow (A) & GYR-QR & $\begin{array}{c}309,780.5 \\
(14.18)\end{array}$ & $\begin{array}{c}67,467,247.02 \\
(76.92)\end{array}$ & $\begin{array}{c}251,067.23 \\
(43.20)\end{array}$ & $\begin{array}{c}68,028,094.74 \\
(75.19)\end{array}$ \\
\hline Inflow (A) & MEX-QR & $\begin{array}{c}1,376,223.95 \\
(63)\end{array}$ & $\begin{array}{c}279,599.4 \\
(0.32)\end{array}$ & $\begin{array}{c}308,843.23 \\
(53.15)\end{array}$ & $\begin{array}{c}1,964,666.58 \\
(2.17)\end{array}$ \\
\hline Subtotal & & $\begin{array}{c}1,686,004.45 \\
(77.18)\end{array}$ & $\begin{array}{c}67,746,846.42 \\
(77.24)\end{array}$ & $\begin{array}{c}559,910.46 \\
(96.35)\end{array}$ & $\begin{array}{c}69,992,761.33 \\
(77.36)\end{array}$ \\
\hline Outflow (B) & QR-GYR & $\begin{array}{c}67,744.15 \\
(3.10)\end{array}$ & $\begin{array}{c}15,374,247 \\
(15.53)\end{array}$ & $\begin{array}{c}16,271.04 \\
(2.80)\end{array}$ & $\begin{array}{c}15,458,262.20 \\
(17.09)\end{array}$ \\
\hline Outflow (B) & QR-MEX & $\begin{array}{c}412,193.56 \\
(18.87)\end{array}$ & $\begin{array}{c}374,706 \\
(0.43)\end{array}$ & $\begin{array}{c}3410.19 \\
(0.59)\end{array}$ & $\begin{array}{c}789,709.75 \\
(0.87)\end{array}$ \\
\hline Subtotal & & $\begin{array}{c}479,937.71 \\
(21.97)\end{array}$ & $\begin{array}{c}15,748,353 \\
(17.95)\end{array}$ & $\begin{array}{c}19,681.24 \\
(3.39)\end{array}$ & $\begin{array}{c}16,247,971.95 \\
(17.96)\end{array}$ \\
\hline Within $(C)$ & QR-QR & $\begin{array}{l}18,547 \\
(0.85)\end{array}$ & $\begin{array}{c}4,216,209 \\
(4.81)\end{array}$ & $\begin{array}{c}1530.19 \\
(0.26)\end{array}$ & $\begin{array}{c}4,236,287.17 \\
(4.68)\end{array}$ \\
\hline $\begin{array}{c}\text { Total } \\
\%\end{array}$ & & $\begin{array}{c}2,184,490.14 \\
100\end{array}$ & $\begin{array}{c}87,711,408 \\
\mathbf{1 0 0}\end{array}$ & $\begin{array}{c}581,121.88 \\
(100)\end{array}$ & $\begin{array}{c}90,477,020.45 \\
(100)\end{array}$ \\
\hline
\end{tabular}

The temporal trajectories of product volumes are illustrated in Figure 3. Inflows outstrip outflows for all three product types for most years. There is a strong trend of increasing inflows (A) over the 2001-2009-time period for livestock as well as meat products. We also note the strong peak in 2004 for both agriculture and meat products, related to a spike in sugar cane molasses demand originating from Veracruz (part of the MEX hinterland region). In terms of outflows (B), we find that these are consistently higher than internal QRoo circulation for both livestock and agriculture over the nine-year study period. Livestock outflows display a similar sharp increase in volume. We found that these relate primarily to increased inflows and outflows of poultry. Taken together, these numbers confirm 
that inflows dominate trade flows in QRoo, and that there is an increasing trend that appears to be associated to the opening of the regional economy in the food sector.
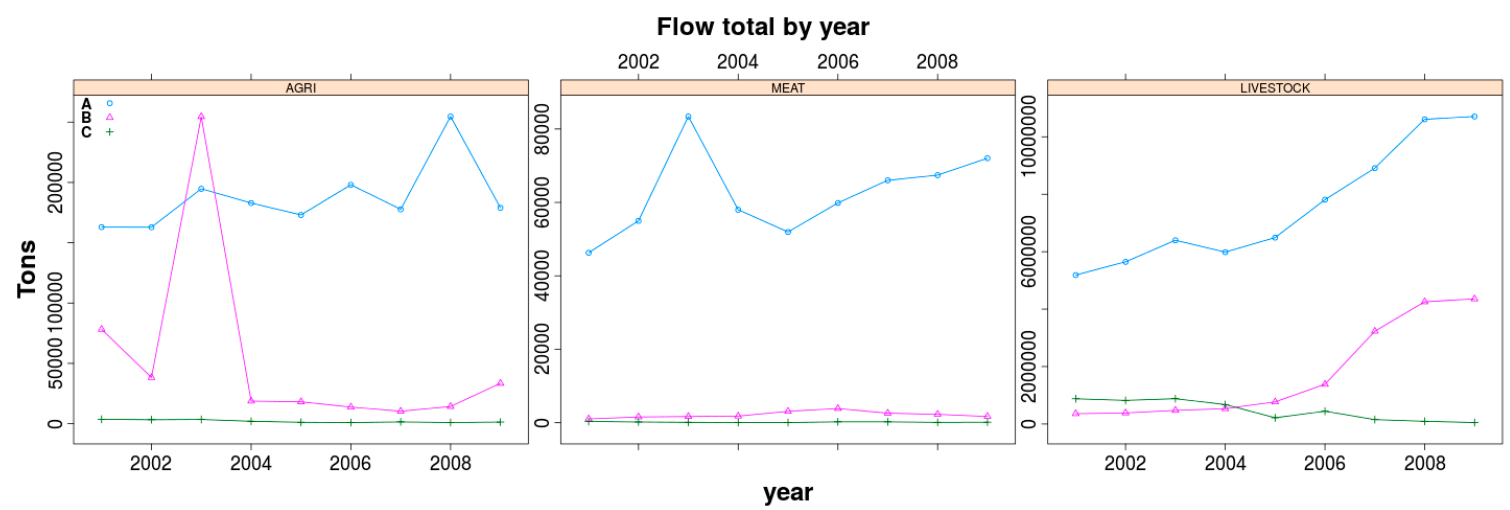

Flow consumption total by year
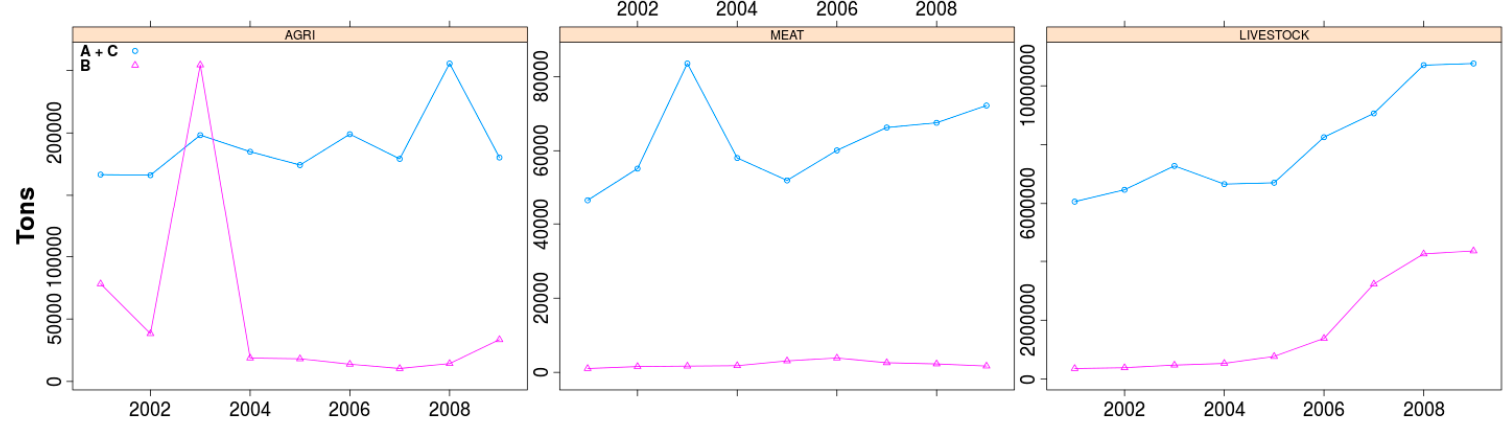

Flow production total by year

$2002 \quad 2004 \quad 2006 \quad 2008$
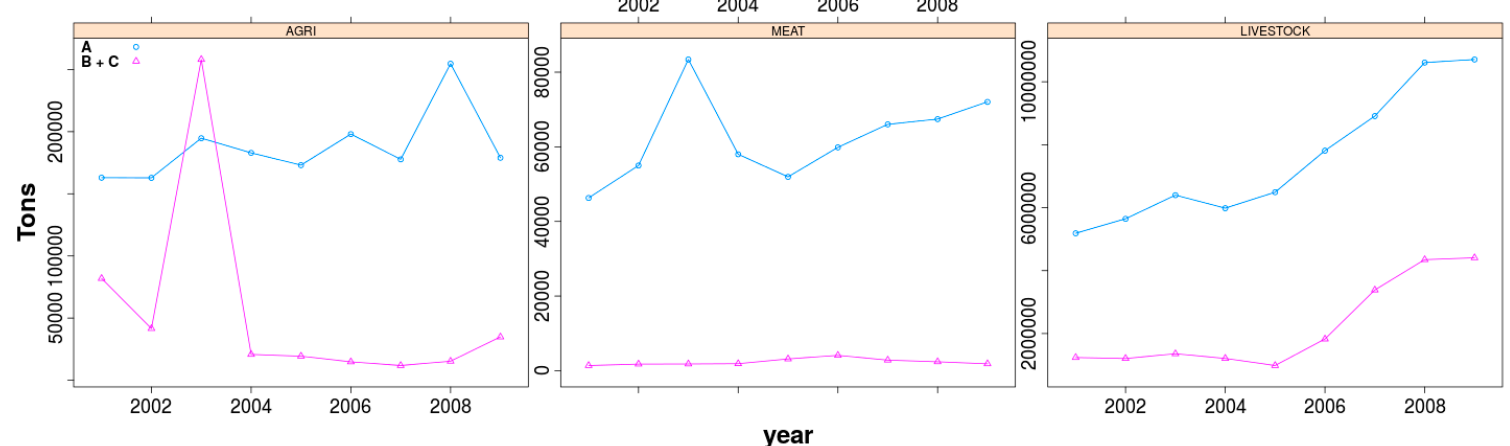

Figure 3. Top panel: flow quantities and import, export and internal flows. Import (Type A: inflows) by product types and destination. (left) Agricultural products (agri); (right) live animals (livestock). Bottom center: animal products (meat). Center panel: consumption derived from flows using quantities for the 2001-2009 time period and three categories of food products. Bottom panel: production derived from flows using quantities for the 2001-2009 time period and three categories of food products.

Inflows to QRoo are dominated mostly by agricultural products but also by staple crops, such as maize, as well as by processed animal products. Fruit and vegetables originate in central Mexico, and processed animal products (bovine, porcine and poultry meat and eggs) from GYR, MEX, and even from the USA and Canada. Poultry from Yucatan (GYR) is the largest generator of live animal import, followed by swine.

Agricultural outflows from QRoo are few in quantity, specialized, and mostly spatially concentrated, though with varying geographic reach. Greenhouse grown peppers, chilies and cucumbers are shipped directly from Felipe Carrillo Puerto to the USA. The majority of jalapeño chili, papaya and watermelon production are shipped to central Mexico, mainly to the central de abastos 
(wholesale produce hub) of Iztapalapa in Mexico City; from there it is redistributed elsewhere in Mexico [61]. Sugar cane concentrate is shipped to Veracruz (MEX). Outflow products that remain within the Greater Yucatan Region include oranges, varied fruits and vegetables as well as papayas and sugar cane concentrate. Sugar cane is shipped to Mérida to produce white bread, pastry products and animal feed, which are distributed across the peninsula and other parts of the country.

Livestock and animal product outflows are more restricted geographically, mainly to destinations within GYR and other states in MEX. Poultry is by far QRoo's largest live export, followed by swine and then cattle. Processed animal product exports are dominated by pork and poultry.

Internal commodity flow data suggest that local production destined for local consumption constitutes only a small portion of the total consumption of QRoo (Figure 3). Local agricultural products consumed include corn, fruits (e.g., papaya, oranges) and varied vegetables (e.g., tomatoes, lettuce), as well as coconut. Live animal flows are dominated by poultry, followed by swine and cattle. Meat products are dominated by processed pork and poultry. Overall, internal flows of agricultural and livestock products in QRoo pale in comparison to what arrives in QRoo from GYR and MEX. Furthermore, our flow dataset does not include flows or production that circulate within municipalities.

\subsection{Production and Consumption (Volume Units) by Product}

Flows that serve as a proxy for consumption in QRoo (types A + C) amount to roughly $87 \%$ of the total flows measured in shipments (transactions) and $82 \%$ measured in volume, while flows that act as proxies for production $(B+C)$ reach close to $20 \%$ of the number of shipments and $22 \%$ of volume in the data. Internal circulation (C) $(6.43 \%$ of shipments, and $4.68 \%$ of total volume) is counted twice since it operates as a proxy for both internal production and consumption. Our proxy measures of trade balance $(B-A,(B+C)-A)$ are both more than $50 \%$ negative (Table 4$)$.

When analyzed over time (Figure 3, center panel), we confirm that agricultural flows used here as measures of consumption $(\mathrm{A}+\mathrm{C})$ in QRoo dominate over those that represent production destined to external and external demand $(\mathrm{B}+\mathrm{C})$. There also appears to be an increasing trend in consumption. Livestock flows present a strong increase in both consumption and production in QRoo, while the consumption component trend and volumes are much larger. The consumption component of processed animal flows (e.g., meat) shows an increasing trend of strong consumption in QRoo, and also of much lower production. Production for meat and agricultural products show that production inside QRoo is much lower than externalized production, with the exception of agriculture in the year 2003. For all three product categories, we find more production taking place outside QRoo than inside.

During the period analyzed, this difference (i.e., negative trade balance) steadily increased for livestock and animal products. This trend suggests that meat consumption has increased in the region, which matches patterns in other rapidly urbanizing regions of the world $[19,62]$, and could reflect, in part, the demands of large scale tourism in northeastern QRoo. In the case of agricultural products, the balance is also strongly negative. However, while QRoo outflows display a negative trend over time, inflows fluctuated (Figure 3, top panel).

\subsection{Decoupling Figures over Time per Each Product Type in Counts and Percentage}

Measuring flow volumes organized by distance, scale, and hinterland categories (QRoo, GYR, MEX) is one way to evaluate general economic decoupling of QRoo, internally and with respect to other regions over time. For the LIVESTOCK product group, the strongest link is with GYR (Figure 4). This link has become stronger over time compared to the circulation within QRoo (Figure 4). For MEAT, the strongest links are with Mexico, until 2003. After 2003, we see GYR becoming stronger than Mexico. For AGRI flows, MEX and GYR are also much stronger than internal flows. These results suggest some form of regional decoupling over time, because flows internal to QRoo are much smaller than external flows from either GYR or Mexico. 

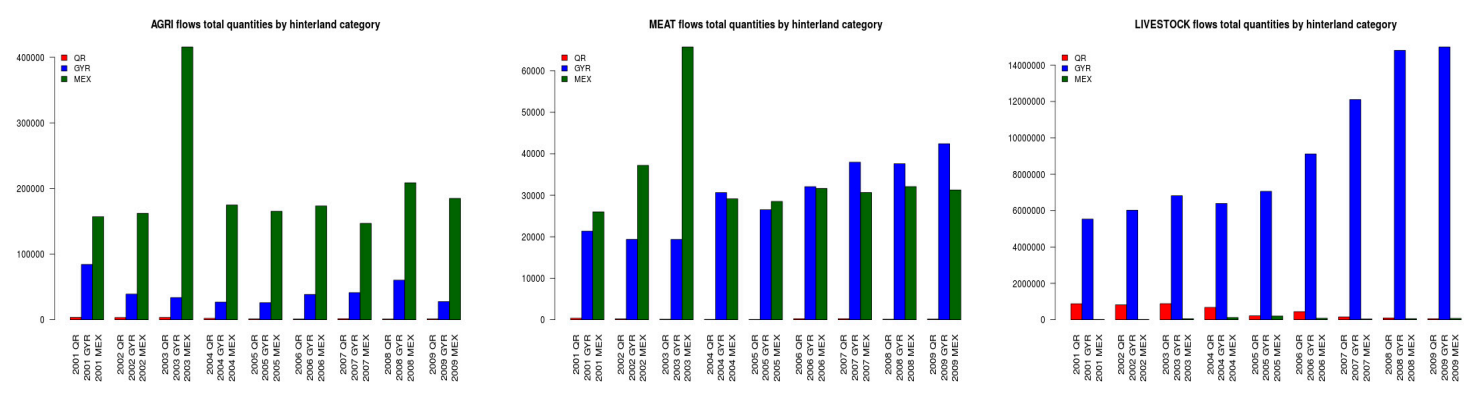

Figure 4. Product flows by year (2001-2009) for QRoo expressed as quantity by hinterland variable (QR, GYT, MEX). The preponderance of external flows (MEX, GYR) suggests increasing decoupling over time, especially in livestock.

An aggregate measure of interaction for the 2001-2009 period using both numbers of transactions/shipments and volumes is captured in the flow dataset (Figure 5). For AGRI, the number of shipments are high in both GYR and MEX compared to QRoo, which suggests strong links to outside areas beyond QRoo. However, the volume of AGRI products originating in MEX is much higher than that coming from GYR. This suggests that higher volumes of AGRI products travel longer distances from locations around MEX, even though they are shipped only slightly more frequently than goods from GYR to QRoo (i.e., larger trailer trucks travel to QRoo from MEX than from GYR).
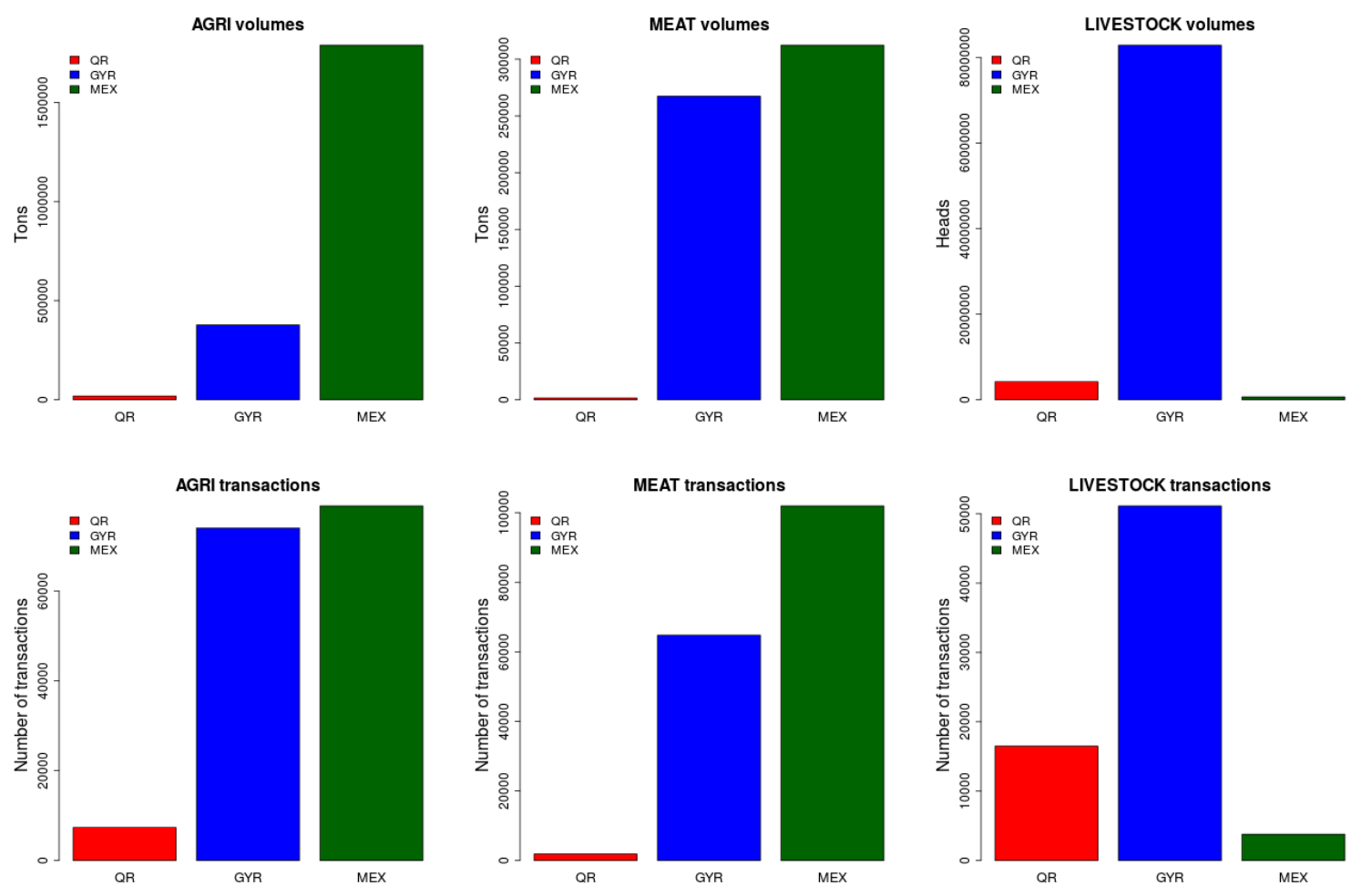

Figure 5. Economic regional decoupling of QRoo expressed by total number shipments/transactions (bottom); and total volumes (top) coming into QRoo by distance/hinterland/scale indicator (QRoo, GYR, MEX), for three type of products: AGRI, LIVESTOCK and MEAT.

Inflows of MEAT originating in GYR and MEX are substantially larger than quantities circulating internally in QRoo suggesting again economic decoupling. LIVESTOCK shipments and volumes suggest strong links between GYR and QRoo, but weak links to MEX. Even internal shipment counts within QRoo are more frequent than those with MEX, suggesting a stronger internal integration of QRoo and a strong meso-regional integration within the Yucatan peninsula (GYR) for livestock 
activities. LIVESTOCK volumes underline the same finding, which is unsurprising given QRoo's standing in the context of animal production in Mexico.

\subsection{Land Displacement and Land Consumption vs. Existing Resources}

To better understand the potential impact of food production and consumption in QRoo, we converted selected food products into land areas taking into account outflows and inflows. We computed the average area of available non-forested land over the 2001-2009 period based on CABS (2009) land cover maps for the same time period. Using that figure as a benchmark, we computed the percentage of potential land use by selected livestock and crops, and animal products combined and reported it by year (Figure 6) (see Appendix A for a list of products and conversion methods). Results indicate that, at any point between 2001-2009, QRoo would have needed to use over $100 \%$ of its non-forest land to maintain its current levels of consumption (flow types $A+C$ ), and to maintain its export oriented land (flows type B) under production (e.g., sugar cane). In other words, had it not been for trade, QRoo would have needed to convert current forested lands, many of which are under some form of protection for conservation, into agricultural lands or pasture. Results also show that the trend toward 2010 was increasing for the subset of selected set of crops, livestock, and animal products combined.

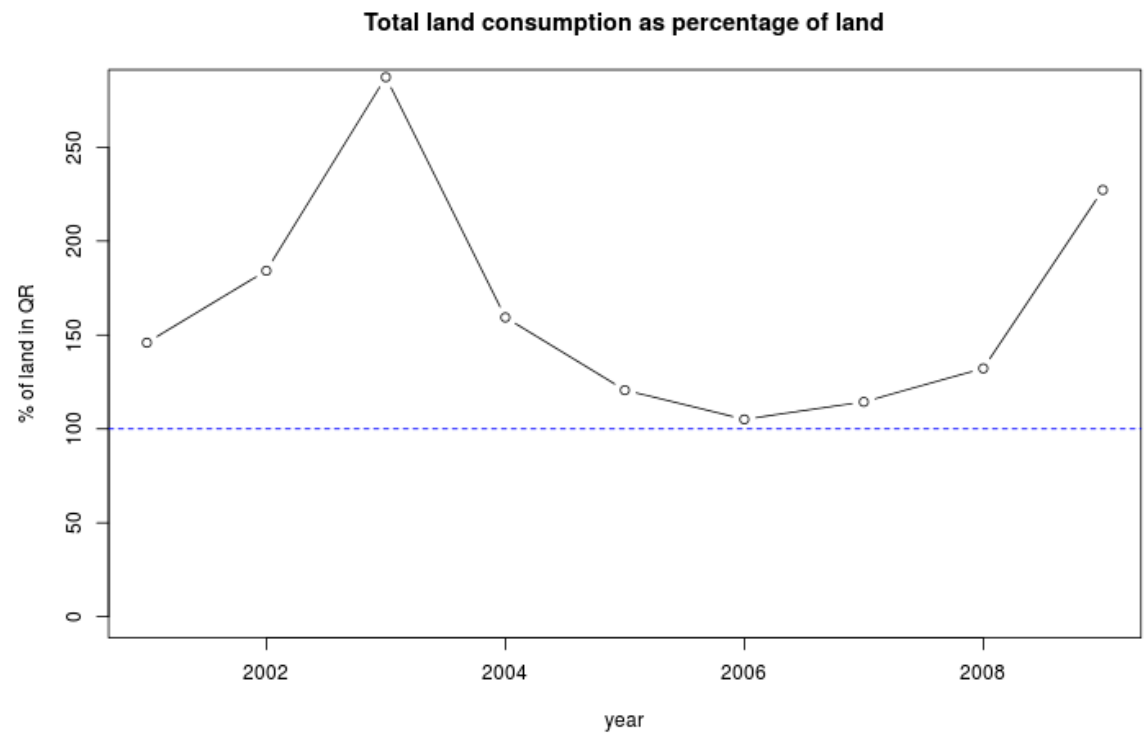

Figure 6. Total land needed to sustain production of flows as a percentage of available non-forested land conversion (Flows type A $+\mathrm{B}+\mathrm{C}$ ) for selected crops and livestock products combined.

The estimates in Figure 6 do not consider the volumes of incoming processed poultry products, or the substantial volumes of crop products that were reported as aggregates (e.g., fruits and vegetables). Based on this conservative estimate, we can state confidently that displacement of land use is present in QRoo. Consequently, we can also state that the 'export' of potential negative externalities and environmental impacts associated with food production processes in other locations is also considerable.

\section{Discussion}

Decoupled regions and displaced productive landscapes are expected to show forest recovery. Primary sector economic activities (e.g., agriculture, cattle ranching) should give way to secondary and tertiary activities. In the last decade, elements of a general forest cover recovery trend have been reported for QRoo by various sources [63-66]. These sources generally point to changes in the political-economic structure of Mexico and the role of QRoo in Mexico's rapid integration into the 
global economy via increased trade and increased tourism. QRoo was not isolated from trade in the past; however, the rapid liberalization of trade and the reorientation of production from extractive to tertiary activities have very likely had a considerable impact on the present arrangement of regional economies and flows, as well as some effect on the type, and direction of land use in QRoo $[44,67,68]$.

These authors' findings coincide with the results of this study. Local agricultural production and cattle ranching does not seem to have affected forestlands during the period analyzed, while trade, measured by inflows and outflows, has steadily increased, coinciding with both the tourism and consequent urban boom along the coast of QRoo. In this sense, we see that the type of forest recovery identified in QRoo, a trajectory considered to be sustainable at one scale of analysis, coincides mostly with a land use displacement $[7,21]$. The measurement of land use displacement is complicated by the difficulty of finding region-specific crop yields and stocking rates. In this research, we utilized Quintana Roo averages over the last decade. In future research we will develop better approximations of the land productivity from the regions from which QR imports food.

Other difficulties stem from potential quality and completeness in the dataset. CEFFPPQR does not have a reliable way to account for flows coming from outside the country or for production and consumption occurring within a municipal unit. There is reason to believe that flows recorded as coming from and going to US border states, such as Laredo or Chihuahua contain international flows. At this point, there is no easy way to validate the accuracy of these data at the municipal level but there might be a way to do it at the aggregate state level. In theory, double counting and distinguishing between flow types A, B and C, should not be an issue given that, by design, the form used to collect data asks explicitly for the origin of the merchandize, as opposed to the origin of the point of departure of the trailer trucks that carry the products. This is because the main concern of CEFPPQR is the spread of diseases, and control point workers have a list of 'forbidden' origin locations for each product (especially in the case of livestock).

QRoo, was constituted in the late 1800s and early 1900s as a decoupled region, dependent on forest-based exports and imports of everything else. Even in recent times, Qroo was never a coupled region, in the same way that the neighboring states of the GYR Campeche and Yucatán were. In a way, it formed part of Yucatan's extended hinterland. As this paper demonstrates, in many regards it remains so. However, on the one hand, over the period analyzed last decade, the volume of flows between QRoo and GYR has decreased in favor of those with locations in the rest of Mexico. This pattern suggests that, while there is still an element of the traditional hinterland at play, a spatial hierarchical gradient might also be uncovered [69,70]. Despite significant markets in states adjacent to QRoo, central Mexico overcomes its relative physical distance, as shown by its larger number of flows and volumes shipped from and to QRoo. On the other hand, recent evidence of the growth of tourism enclaves such as Cancun and Playa del Carmen into contemporary urban centers, as well as the increased importance of the capital city of Chetumal over the last two decades, suggest the beginning of an incipient intra-regional coupling. Further research using our commodity flow dataset at a municipal scale will investigate evidence of changing urban-rural relationships within QRoo and between cities and the countryside. For example, the most important product in terms of number of shipments and volumes between municipalities within QRoo is a weed called zacate rojo (Pennisetum cupreum), an invasive grass that grows spontaneously around fields and is used for roofing rustic tourist constructions in beach resorts. Further research will also investigate the governance and food security angles of multi-scalar food system impact analysis, and to which level, national scale actors, from the private and public sectors, are influencing the consumption patterns (e.g., tourism and migration from other wealthier parts of Mexico).

\section{Conclusions}

This study presents a unique analysis of food product flows in southeastern Mexico for the time-period 2001-2009. In the state of QRoo, a strong negative flow balance is persistent, with inflows overpowering outflows of food product transactions, shipments and volumes by factors that range 
from four, in the case of agricultural products, and to 30, in the case of animal products such as bovine meat and poultry. This dependency on external flows is not new, but it has intensified over the last decades. In addition, the geographic structure of QRoo's dependency on external food flows seems to be shifting from the greater Yucatan peninsula region (GYR) to the rest of Mexico, especially Mexico City and its surrounding area. This phenomenon is increasingly true for agricultural and meat products. This pattern signals a process of regional decoupling, at least for certain products such as produce and processed meat. That said, GYR and especially the state of Yucatan, maintain strong historical production links with QRoo, as demonstrated by flows of cattle, poultry and selected crop products. The intensity of the relationship, manifested in the high frequency of low volume flows suggest that QRoo is still a type of hinterland for the state of Yucatan and in general the GYR (Yucatan Peninsula), and that together these states still form a cultural and economic region with strong links. Local production (flows within QRoo) is small and can be split into three parts: (a) export-oriented specialized crops destined for selected points in Mexico and abroad; (b) livestock and meat (especially swine) oriented to the peninsular and urban market; and (c) local production of low yield agriculture that typically stays within the state, but is not enough to satisfy its demand.

When selected crops and livestock products are converted into land units, our study demonstrates that the high levels of dependency on external food inflows translate into substantial levels of land use displacement. The level of displacement reported varies over time, type of product and scale. Even with a subset of products and very conservative assumptions, they amount to over $100 \%$ of the available (non-forested) land in QRoo for the period analyzed.

Incorporating flows and trade into a measure of sustainable outcomes helps to clarify the spatial correspondence between production, consumption and land patterns over space and time. In a contemporary context, most developing countries are opening their economies to global trade and redefining their land use priorities accordingly, both in terms of products and scale. Given this reality, it is important to consider whether national governments are prioritizing policies and management practices that 'optimize' land uses at the local or even regional scales (i.e., whether they are contributing towards development and/or environmental goals, as in QRoo). In contrast, countries may instead aim to optimize outcomes for broader national and global scales, reflecting and possibly deepening differences that mimic a global division of labor. While this paper does not answer all questions related to the topic, our findings and the framework utilized help highlight the use of non-standard but systematic datasets to capture processes at scales other than national or global.

Future analyses drawing on these data will incorporate finer detail in spatial scales to answer questions about the redefinition of urban-rural links, examine the relationships of consumption patterns to tourism (a major economic and urbanizing force in the region), and employ more sophisticated methods for the conversion of flow volumes to land units.

Acknowledgments: We thank Billie Lee Turner II, Daniel A. Griffith, Jaqckeline Geoghegan who participated in the early phase of the research design and read early versions of this research. Laura Mansur patiently cleaned major portions of the database. We are deeply indebted to Elias Barranco Euan and Rosi May Pacheco in Chetumal for introducing us to the CPFPPAR database. We also thank Susannah McCandless for copy editing the manuscript.

Author Contributions: Marco Millones, Birgit Schmook and John Rogan conceived and designed the original research and fieldwork; Millones performed the fieldwork with the assistance of Schmook; Millones performed preliminary data analysis and Benoit Parmentier executed the final data analysis; Rogan, Schnook contributed with materials and statistics about agricultural products as well as bibliographical references; Millones, Parmentier and Schmook wrote the paper. Rogan revised the manuscript.

Conflicts of Interest: The authors declare no conflict of interest.

\section{Appendix A. Conversion from Quantities/Volumes to Area Units by Product Type}

Selected agricultural product volumes were converted to area, according to average yields in metric tons per hectare provided by the Servicio de Informacion Agricola y Pecuaria (SIAP) [71] service 
for the state of Quintana Roo. Sugar cane to molasses conversion was performed using Food and Agricultural Organization (FAO) [72] estimates (see Table A1).

Table A1. Selected Agricultural Products (AGRI).

\begin{tabular}{cc}
\hline Product & Tn/Ha \\
\hline Molasses & 1.8 \\
Watermelon & 10.23 \\
Orange & 12.13 \\
Papaya & 71.24 \\
Maize & 0.84 \\
Banana & 12.67 \\
Lemon & 17.84 \\
Rice & 5 \\
Tomato & 28.625 \\
Sugar & 53.15 \\
Habanero Chile & 10 \\
Avocado & 20.46 \\
Sorgo & 2.92 \\
Corn the cob & 5.23 \\
Jalapeño Chile & 10.039 \\
\hline Sources: SIAP [71] and Paturnau [72].
\end{tabular}

Livestock units were converted to area using the equivalencies from The John Nix Farm Management Picketbook [73]. The numbers used can be found in Table A2.

Table A2. Selected Livestock (LIVESTOCK).

\begin{tabular}{cc}
\hline Type & Head/Ha \\
\hline Adult Cow & 1 \\
Weaned Calves & 1.43 \\
1-2 year old Calves & 1.54 \\
Unweaned male & 2.5 \\
calves & 12.5 \\
Sheep & 6.25 \\
Goat & 1.25 \\
Horse & 5 \\
Pig &
\end{tabular}

Finally, processed animal products such as meat, dairy and eggs were converted using figures provided by the landshare.org project [74] (Table A3).

Table A3. Selected Animal Processed Products (MEAT).

\begin{tabular}{cc}
\hline Product & Head/HA \\
\hline Poultry & 0.64 \\
Bovine meat & 1.352 \\
Pork meat & 1.352 \\
Dairy & 0.123 \\
Eggs (pasteurized) & 0.569 \\
Sheep meat & 1.352
\end{tabular}

Source: http:/ / www.landshare.org/how-to-feed-a-city.html [74]. 


\section{References}

1. Steffen, W.; Sanderson, A.; Tyson, P.D.; Jäger, J.; Matson, P.A.; Moore, B., III; Oldfield, F.; Richardson, K.; Schellnhuber, H.J.; Turner, B.L.; et al. Global Change and the Earth System: A Planet under Pressure; Springer: Berlin/Heidelberg, Germany; New York, NY, USA, 2004.

2. Carpenter, S.R.; Mooney, H.A.; Agard, J.; Capistrano, D.; DeFries, R.S.; Díaz, S.; Dietz, T.; Duralappah, A.K.; Oteng-Yeboah, A.; Perelral, H.M.; et al. Science for managing ecosystem services: Beyond the Millennium Ecosystem Assessment. Proc. Natl. Acad. Sci. USA 2009, 106, 1305-1312. [CrossRef] [PubMed]

3. De Fries, R.S.; Foley, J.A.; Asner, G.P. Land use choices: Balancing human needs and ecosystem function. Front. Ecol. Environ. 2004, 2, 249-257. [CrossRef]

4. Phalan, B.; Onial, M.; Balmford, A.; Green, R.E. Reconciling Food Production and Biodiversity Conservation: Land Sharing and Land Sparing Compared. Science 2011, 333, 1289-1291. [CrossRef] [PubMed]

5. Kastner, T.; Rivas, M.J.I.; Koch, W.; Nonhebel, S. Global changes in diets and the consequences for land requirements for food. Proc. Natl. Acad. Sci. USA 2012, 109, 6868-6872. [CrossRef] [PubMed]

6. Alexander, P.; Rounsevell, M.D.A.; Dislich, C.; Dodson, J.R.; Engström, K.; Moran, D. Drivers for global agricultural land use change: The nexus of diet, population, yield and bioenergy. Glob. Environ. Chang. 2015, 35, 138-147. [CrossRef]

7. Meyfroidt, P.; Lambin, E.F.; Erb, K.-H.; Hertel, T. Globalization of land use: Distant drivers of land change and geographic displacement of land use. Curr. Opin. Environ. Sustain. 2013, 5, 438-444. [CrossRef]

8. Weinzettel, J.; Hertwich, E.G.; Peters, G.P.; Steen-Olsen, K.; Galli, A. Affluence drives the global displacement of land use. Glob. Environ. Chang. 2013, 23, 433-438. [CrossRef]

9. D'Odorico, P.; Carr, J.A.; Laio, F.; Ridolfi, L.; Vandoni, S. Feeding humanity through global food trade. Earth's Future 2014, 2, 458-469. [CrossRef]

10. Hubacek, K.; Feng, K.; Chen, B.; Kagawa, S. Linking Local Consumption to Global Impacts. J. Ind. Ecol. 2016, 20, 382-386. [CrossRef]

11. Davis, K.F.; Rulli, M.C.; D'Odorico, P. The global land rush and climate change. Earth's Future 2015, 3, 298-311. [CrossRef]

12. Ostrom, E. Polycentric systems for coping with collective action and global environmental change. Glob. Environ. Chang. 2010, 20, 550-557. [CrossRef]

13. Sikor, T.; Auld, G.; Bebbington, A.J.; Benjaminsen, T.A.; Gentry, B.S.; Hunsberger, C.; Izac, A.M.; Margulis, M.E.; Plieninger, T.; Schroeder, H.; et al. Global land governance: From territory to flow? Curr. Opin. Environ. Sustain. 2013, 5, 522-527. [CrossRef]

14. Turner, B.L.; Lambin, E.; Reenberg, A. The Emergence of Land Change Science for Global Environmental Change and Sustainability. Proc. Natl. Acad. Sci. USA 2007, 104, 20666-20671. [CrossRef] [PubMed]

15. Rounsevell, M.D.; Pedroli, B.; Erb, K.H.; Gramberger, M.; Busck, A.G.; Haberl, H.; Kristensen, S.; Kuemmerle, T.; Lavorel, S.; Lindner, M.; et al. Challenges for land system science. Land Use Policy 2012, 29, 899-910. [CrossRef]

16. Wackernagel, M.; Rees, W. Our Ecological Footprint: Reducing Human Impact on the Earth; New Society Publishers: Gabriela Island, BC, Canada, 1996.

17. Walker, R. Urban sprawl and natural areas encroachment: Linking land cover change and economic development in the Florida Everglades. Ecol. Econ. 2001, 37, 357-369. [CrossRef]

18. Seto, K.C.; de Groot, R.; Bringezu, S.; Erb, K.; Graedel, T.E.; Ramankutty, N.; Reenberg, A.; Schmidt, O.J.; Skole, D.L. Stocks, flows, and prospects of land. In Linkages of Sustainability; Graedel, T.E., Van der Voet, E., Eds.; Strüngman Forum: Cambridge, UK, 2009.

19. Seto, K.C.; Reenberg, A.; Boone, C.G.; Fragkias, M.; Haase, D.; Langanke, T.; Marcotullio, P.; Munroe, D.K.; Olah, B.; Simon, D. Urban land teleconnections and sustainability. Proc. Natl. Acad. Sci. USA 2012, 109, 7687-7692. [CrossRef] [PubMed]

20. Meyfroidt, P.; Lambin, E.F. Forest transition in Vietnam and displacement of deforestation abroad. Proc. Natl. Acad. Sci. USA 2009, 106, 16139-16144. [CrossRef] [PubMed]

21. Meyfroidt, P.; Rudel, T.K.; Lambin, E.F. Forest transitions, trade, and the global displacement of land use. Proc. Natl. Acad. Sci. USA 2010, 107, 20917-20922. [CrossRef] [PubMed]

22. Friis, C.; Reenberg, A. Land Grab in Africa: Emerging Land System Drivers in a Teleconnected World; GLP-IPO: Copenhagen, Denmark, 2010. 
23. Turner, M.G. Landscape ecology: The effect of pattern on process. Annu. Rev. Ecol. Syst. 1989, 20, $171-197$. [CrossRef]

24. Von Thünen, J.H. Der isolierte Staat in Beziehung auf Landwirtschaft und Nationalökonomie. In Von Thünen's Isolated State; Hall, P., Ed.; Pergamon Press: Oxford, UK, 1966. (Original in 1876 In German)

25. Angelsen, A. Forest Cover Change in Space and Time: Combining the von Thunen and Forest Transition Theories. World Bank Policy Working Paper 4117. 2007. Available online: https://openknowledge. worldbank.org/handle/10986/7147 (accessed on 28 October 2016).

26. Grau, R.; Kuemmerle, T.; Macchi, L. Beyond land sparing versus land sharing: Environmental heterogeneity, globalization and the balance between agricultural production and nature conservation. Curr. Opin. Environ. Sustain. 2013, 5, 477-483. [CrossRef]

27. Mather, A.S. The forest transition. Area 1992, 24, 367-79.

28. Rudel, T.K.; Coomes, O.; Moran, E.; Angelsen, A.; Achard, F.; Lambinand, E.; Xu, J. Forest transitions: Towards an understanding of global land use change. Glob. Environ. Chang. 2005, 14, 23-31. [CrossRef]

29. Perz, S.G. Grand Theory and Context Specificity in the Study of Forest Dynamics: Forest Transition Theory and Other Directions. Prof. Geogr. 2007, 59, 105-114. [CrossRef]

30. Rudel, T.; Schneider, L.C.; Uriarte, M.; Turner, B.L.; DeFries, R.; Lawrence, D.; Geoghegan, J.G.; Hecht, S.; Ickowitz, A.; Lambin, E.; et al. Agricultural Intensification and Changes in Cultivated Areas, 1970-2005. Proc. Natl. Acad. Sci. USA 2010, 106, 20675-20680. [CrossRef] [PubMed]

31. Mather, A.S.; Needle, C.L. The forest transition: A theoretical basis. Area 1998, 30, 117-124. [CrossRef]

32. Hecht, S. Invisible forests: The political ecology of forest resurgence in El Salvador. In Liberation Ecologies: Environment, Development, Social Movements; Peet, R., Watts, M.W., Eds.; Routledge: London, UK; New York, NY, USA, 2004.

33. Schmook, B.; Radel, C. International labor migration from a tropical development frontier: Globalizing households and an incipient forest transition: The Southern Yucatán case. Hum. Ecol. 2008, 36, 891-908. [CrossRef]

34. Turner, B.L. Sustainability and forest transitions in the southern Yucatán: The land architecture approach. Land Use Policy 2010, 27, 170-179. [CrossRef]

35. Walker, R.T.; Harwell, C. Land use dynamics and ecological transition: The case of South Florida. Urban Ecosyst. 1997, 1, 37-47. [CrossRef]

36. Bruckner, M.; Fischer, G.; Tramberend, S.; Giljum, S. Measuring telecouplings in the global land system: A review and comparative evaluation of land footprint accounting methods. Ecol. Econ. 2015, 114, 11-21. [CrossRef]

37. Chaudhary, A.; Kastner, T. Land use biodiversity impacts embodied in international food trade. Glob. Environ. Chang. 2016, 38, 195-204. [CrossRef]

38. Walker, R.; Solecki, W.D. Theorizing land-cover and land-use change: The case of the Florida Everglades and its degradation. Ann. Assoc. Am. Geogr. 2004, 94, 311-238. [CrossRef]

39. Córdoba Ordóñez, J. Propuesta de tipificación municipal del comportamiento demográfico en el estado de Yucatán (México). Anales de Geografía de la Universidad Complutense 1999, 19, 47-70. (In Spanish)

40. Lutz, W.; Prieto, L.; Sanderson, W. (Eds.) Population, Development and Environment on the Yucatan Peninsula: From Ancient Maya to 2030; International Institute for Applied Systems Analysis: Luxemburg, 2000.

41. Farris, N.M. Maya Society under Colonial Rule: The Collective Enterprise of Survival; Princeton Press: Princeton, NJ, USA, 1984.

42. Klepeis, P.; Turner, B.L. Integrated land history and global change science: The example of the Southern Yucatan Peninsular Region project. Land Use Policy 2001, 18, 27-39. [CrossRef]

43. Macías Zapata, G.A. La Península Fracturada. Conformación Marítima, Social y Forestal del Territorio Federal de Quintana Roo. 1884-1902; Colección Peninsular. Centro de Investigaciones y Estudios Superiores en Antropología Social-CIESAS, Universidad de Quintana Roo: Chetumal, Mexico, 2002. (In Spanish)

44. Macías Zapata, G.A. (Ed.) El vacío Imaginario. Geopolítica de la Ocupación Territorial en el Caribe Oriental Mexicano; Centro de Investigaciones y Estudios Superiores en Antropología Social-CIESAS, México DF. I Congreso del Estado de Quintana Roo, X Legislatura: Chetumal, Mexico, 2003. (In Spanish)

45. Villalobos Gonzales, M.H. El Bosque Sitiado. Asaltos Armados, Concesiones Forestales y Estrategias de Resistencia Durante la Guerra de Castas; Centro de Investigaciones y Estudios Superiores en Antropologia Social: Tlalpan, Mexico, 2006. (In Spanish) 
46. Primack, B.; Bray, D.; Galleti, H.A.; Ponciano, I. Timber, Tourists, and Temples: Conservation and Development in the Maya Forest of Belize, Guatemala, and Mexico; Island Press: Washington, DC, USA, 1988.

47. Turner, B.L., II; Geoghegan, J.G.; Foster, D.R. (Eds.) Integrated Land Change Science and Tropical Deforestation in the Southern Yucatán: Final Frontiers; Oxford University Press: Oxford, UK, 2004.

48. Coll-Hurtado, A.; Godínez Calderón, M.L. La Agricultura en México: Un atlas en Blanco y Negro. Colección Textos Monográficos-Economía; Instituto de Geografía, Universidad Nacional Autónoma de México: Mexico City, Mexico, 2004. (In Spanish)

49. Klepeis, P.; Vance, C. Neoliberal policy and deforestation in southeastern Mexico: An assessment of the PROCAMPO Program. Econ. Geogr. 2003, 79, 221-240. [CrossRef]

50. Klepeis, P. Development policies and tropical deforestation in the southern Yucatan peninsula: Centralized and decentralized approaches. Land Degrad. Dev. 2003, 14, 541-561. [CrossRef]

51. Torres, R.; Momsen, J. Gringolandia: The Construction of a New Tourist Space in Mexico. Ann. Assoc. Am. Geogr. 2005, 95, 314-335. [CrossRef]

52. Hernández Aguilar, M.L.; Garcia de Fuentes, A.; Córdoba Ordóñez, J. Distribución Territorial de la Producción Agropecuaria en la Península de Yucatán Hacia Fines de Siglo XX; CINVETAV-PNUD-UNAM: Mexico City, Mexico, 2004. (In Spanish)

53. Flachenberg, H.; Galletti, H. A Forest Management in Quintana Roo, Mexico. In Timber, Tourists, and Temples: Conservation and Development in the Maya Forest of Belize, Guatemala, and Mexico; Primack, B., Bray, D., Galleti, H.A., Ponciano, I., Eds.; Island Press: Mexico City, Mexico, 1998.

54. Torres Rojo, J.M. Estudio de Tendencias y Perspectivas del Sector Forestal en America Latina Documento de Trabajo. Informe Nacional. México. Secretaria de Medio Ambiente y Recursos Naturales de México (SEMARNAT). 2004. Available online: ftp://ftp.fao.org/docrep/fao/009/j2215s/j2215s00.pdf (accessed on 15 October 2016). (In Spanish)

55. Bray, D.B.; Merido Perez, L.; Barrt, D. Los Bosques Comunitarios de México. Manejo Sustentable de Paisajes Forestales. 2011. Available online: http://www.nacionmulticultural.unam.mx/empresasindigenas/docs/ 2059.pdf (accessed on 7 November 2016).

56. SAGARPA. Diagnostico Agropecuario Forestal y Pesquero del Estado de Quintana Roo. 2010. Available online: http:/ / www.sagarpa.gob.mx/Delegaciones/quintanaroo/Lists/Difusin\%202009/Attachments / 18/Diagn\%C3\%B3stico_sectorial_QRoo10.pdf (accessed on 1 December 2015).

57. Colunga-Garcia, C.; Marin, P.; Larqué Saavedra, A. Naturaleza y Sociedad en el Area Maya: Pasado, Presente y Futuro; CICY-Academia Mexicana de Ciencias: Mérida, Mexico, 2003. (In Spanish)

58. Islebe, G.A.; Calmé, S.; León-Cortés, J.L.; Schmook, B. Biodiversity and Conservation of the Yucatán Peninsula; Springer: New York, NY, USA, 2015.

59. Secretaria Nacional del Medio Ambiente-SEMARNAT. 2011. Available online: http:/ /www.semarnat.gob. $\mathrm{mx} /$ leyesynormas/Pages/leyessectorfederal.aspx (accessed on 5 July 2010).

60. Center for Applied Biodiversity Science (CABS) at Conservation International (CI). El Colegio de la Frontera SUR (ECSUR), Belize Tropical Forest Studies, and Consejo Nacional de Areas Protegidas-World Conservation Society (WCS). 2009. Available online: https://www.ncbi.nlm.nih.gov/pmc/articles/ PMC3414527/bin/pone.0042309.s001.zip (accessed on 3 December 2014).

61. Keys, E. Exploring market based development: Market intermediaries and farmers in Calakmul, Mexico. Geogr. Rev. 2005, 95, 24-46. [CrossRef]

62. Emel, J.; Neo, H. Killing for profit: Global livestock industries and their socio-ecological implications. In Global Political Ecology; Peet, R., Robbins, P., Watts, M., Eds.; Routledge: London, UK; New York, NY, USA, 2011; pp. 67-83.

63. Klooster, D. Forest transitions in Mexico: Institutions and forests in a globalized countryside. Prof. Geogr. 2003, 55, 227-237.

64. Schneider, L.C.; Geoghegan, J. Land abandonment in an agricultural frontier after a plant invasion: The case of bracken fern in southern Yucatán, Mexico. Agric. Resour. Econ. Rev. 2006, 35, 167-177. [CrossRef]

65. Radel, C.; Schmook, B. Male Transnational Migration and its Linkages to Land-Use Change in a Southern Campeche Ejido. J. Latin Am. Geogr. 2008, 7, 59-83. [CrossRef]

66. Rueda, X. Understanding deforestation in the southern Yucatán: Insights from a sub-regional, multi-temporal analysis. Reg. Environ. Chang. 2010, 10, 175-190. [CrossRef] 
67. Córdoba Ordóñez, J.; Fuentes, G.; Azcárate, C. Modernismo ambiental frente a tradición: Problemas y perspectivas en el caso de la península de Yucatan (Mexico). Anales de Geografía de la Universidad Complutense 2000, 20, 235-251. (In Spanish)

68. Eastmond, A. Agricultura y Ganadería. In Atlas de Procesos Territoriales de Yucatán; García de Fuentes, A., Córdoba Ordóñez, J., Eds.; Universidad Autónoma de Yucatán: Mérida, Mexico, 1999. (In Spanish)

69. Jutila, S.T. Spatial Macroeconomic models. Pap. Reginal Sci. 1973, 30, 39-57. [CrossRef]

70. Millones, M. Settlement Classification Using a Rural-Urban Continuum in Cusco, Peru. Master's Thesis, University of Miami, Coral Gables, FL, USA, 2006.

71. Servicio de Información Agrícola y Peruaria-SIAP. Available online: http://infosiap.siap.gob.mx:8080/ agricola_siap_gobmx/ResumenDelegacion.do (accessed on 15 October 2016).

72. Paturnau, J.M. Alternative Uses of Sugarcane and Its by Products in Agroindustries. Available online: http://www.fao.org/docrep/003/s8850e/S8850E03.htm (accessed on 15 October 2016).

73. John Pix Pocketbook. Available online: http://www.thepocketbook.biz/ (accessed on 15 October 2016).

74. The Landshare Project. Available online: http://www.landshare.org/uploads/7/5/4/1/7541639/data_ and_assumptions.pdf (accessed on 15 October 2016).

(C) 2016 by the authors; licensee MDPI, Basel, Switzerland. This article is an open access article distributed under the terms and conditions of the Creative Commons Attribution (CC-BY) license (http://creativecommons.org/licenses/by/4.0/). 